УДК 582.284.3

\title{
ДОСЛІДЖЕННЯ РІДКІСНИХ ВИДІВ МІКОБІОТИ НА ТЕРИТОРІЇ НПП «ГУЦУЛЫЩИНА» В 2020 РОЦІ
}

\author{
C.I. Фокшей, О.О. Погрібний \\ Наиіональний природний парк «Гуиульщина» \\ вул. Дружби, 84, Косів, 78601, Україна \\ e-mail: stellaannafr@gmail.com
}

Охорона природи, збереження біоти, екосистем $є$ одним із головних завдань сучасного суспільства. Виявлення та охорона рідкісних видів в Національному природному парку (НПП) «Гуцульщина» триває впродовж 18 років, з початку створення установи. Серед раритетних видів мікобіоти, що потребують охорони на території парку є 21 макроміцет. В 2020 р. тривав моніторинг рідкісних таксонів мікобіоти на вже відомих локалітетах та виявлення нових.

Об'єктом досліджень слугували види грибів, що включені до Червоної книги України (ЧКУ) та списків Міжнародного союзу охорони природи (МСОП) на території НПП «Гуцульщина». При встановленні приналежності та природоохоронної категорії для рідкісних видів використовували критерії Червоної книги України та IUCN $[5,7]$. Ідентифікацію видів проводили за допомогою сучасних вітчизняних та закордонних визначників $[3,4,7,8]$ i мікроскопа Біолам. Назви макроміцетів та прізвища авторів при таксонах подано за Index Fungorum [9].

Впродовж 18 років на території НПП «Гуцульщина» виявлено та закартовано локалітети 20 видів макроміцетів, що включені до ЧКУ та 2 до списків IUCN. A саме: Anthurus archeri (Berk.) E. Fisch. (ЧКУ), Butyriboletus regius (Krombh.) D. Arora \& J.L. Frank (ЧКУ), Catathelasma imperiale (Р. Karst.) Singer (ЧКУ, MCОП), Clavariadelphus pistillaris (L.) Donk (ЧКУ), Cortinarius caperatus (Pers.) Fr. (МСОП), Grifola frondosa (Dicks.) Gray (ЧКУ), Gomphus clavatus (Pers.) Gray (ЧКУ), Hericium coralloides (Scop.) Pers. (ЧКУ), Lactarius lignyotus Fr. (ЧКУ), Leucoagaricus nympharum (Kalchbr.) Bon (ЧКУ), Leucocortinarius bulbiger (Alb. \& Schwein.) Singer (ЧКУ), Mutinus caninus (Huds.) Fr (ЧКУ), Mutinus ravenelii (Berk. \& M.A. Curtis) E. Fisch. (ЧКУ), Phaeolepiota aurea (Matt.) Maire (ЧКУ), Phylloporus pelletieri (Lév.) Quél. (ЧКУ), Polyporus umbellatus (Pers.) Fr. (ЧКУ), Pseudoboletus parasiticus (Bull.) Šutara (ЧКУ), Russula turci Bres. (ЧКУ), Sparassis crispa (Wulfen) Fr. (ЧКУ), Strobilomyces strobilaceus (Scop.) Berk. (ЧКУ), Tricholoma focale (Fr.) Ricken. (ЧКУ).

В 2020 р. здійснено 53 мікологічні експедиції в весняно-літньо-осінній період 3 метою моніторингу локалітетів рідкісних видів мікобіоти. Під-час досліджень зареєстровано нові локалітети 10 раритетних макроміцетів, що включені до ЧКУ та МСОП, знайдених в попередні роки. Серед них:

Anthurus archeri - вид з диз'юнктивним ареалом, макроміцет-ефемер. Росте в листяних та мішаних лісах, на луках. Плодоносить 3 травня по грудень. В Україні поширений в Закарпатській та івано-Франківській обл. [7]. В Українських Карпатах гриб виявлений на 
території Карпатського біосферного заповідника (КБЗ), Природного заповідника «Горгани», НПП «Зачарований край», НПП «Синевір», НПП «Сколівські Бескиди», Ужанського НПП [2].

В НПП «Гуцульщина» Anthurus archeri трапляється на всій території НПП «Гуцульщина» [6]. Вид плодоносить щорічно, великими групами.

В 2020 р. знайдено одне нове місцезростання 27.07. в Шешорському природоохоронному відділенні (ПНДВ), полонина Росохата та було зафіксовано плодоношення на вже відомих місцях: 24.06., 24.08., 16.11. в Старокутському ПНДВ, хр. Голиця, смереково-буковому лісі. Крім того масове плодоношення, понад 100 екземплярів фіксували в травні на приватній ділянці в с. Соколівка, присілок Верхній Мокрий. Локалітети закартовані та взяті під охорону (рис. 1). Вид підтримується в колекції чистих культур НПП «Гуцульщина».

Butyriboletus regius - неморальний вид з диз'юнктивним ареалом. Росте в листяних лісах 3 Fagus sylvatica L. та Quercus robur L. Плодоносить з червня до вересня. В Україні поширений в Закарпатській, Полтавській, Донецькій, Черкаській областях. [7].

В НПП «Гуцульщина» Butyriboletus regius виявлено в Кутському лісництві (Державне підприємство (ДП) «Кутське лісове господарство»), Старокутському ПНДВ [6]. Вид рідкісний на території парку. В 2020 р. нових локалітетів не реєстрували. 26. 07. B. regius плодоносив на вже раніше відмічених місцях: Кутське лісництво (ДП Кутське лісове господарство), кв. 25, вид. 24, смереково-буковий ліс та 22.09. - Старокутське ПНДВ, хр. Голиця, смереко-буковий ліс. Локалітети закартовані та взяті під охорону (рис. 1).

Clavariadelphus pistillaris - неморальний вид з диз'юнктивним ареалом. Росте в листяних лісах $з$ Fagus sylvatica L.. Плодоносить 3 кінця серпня до листопада. В Україні поширений в Правобережному та Лівобережному Поліссі, Карпатах, Правобережному та Харківському Лісостепу, Криму [7]. В Українських Карпатах вид зафіксований в КБ3 [2].

В НПП «Гуцульщина» Clavariadelphus pistillaris зареєстровано два локалітети: Старокутське ПНДВ та Яблунівське лісництво (ДП «Кутське лісове господарство) [6]. В 2020 році нових локалітетів не виявлено. 22.09. зафіксовано два плодові тіла на вже відомому місці в Старокутському ПНДВ, буковому лісі. Локалітет закартовано та взято під охорону (рис. 1).

Hericium coralloides - реліктовий вид. Росте в букових лісах. Плодоносить з серпня до кінця жовтня. В Україні трапляється у Волинській, Київській, Чернівецькій, Львівській, Тернопільській, Закарпатській, Черкаській, Дніпропетровській, Донецькій областях та Криму [7]. В Українських Карпатах вид знайдено в КБЗ, НПП «Зачарований край», Карпатському НПП, НПП «Синевир», Ужанському НПП [2].

В НПП «Гуцульщина» Hericium coralloides виявлено в Старокутському та Косівському ПНДВ, Космацькому лісництві (ДП «Кутське лісове господарство»), Великорожинському лісництві (Районне підприємство (РП) «Райагроліс») [6]. В 2020 році виявлено три нових місцезростання: 20.10. в Старокутському ПНДВ, хр. Голиця (кв. 3, вид. 2), буковому лісі; 27.10. в Косівському ПНДВ, ППП № 9, ялицево-буковому лісі, 14.11. в Шешорському ПНДВ, хр. Брусний (кв. 28, вид. 5), смереково-буковому лісі. Також фіксували плодоношення 24.09. і 19.11. Косівському ПНДВ, хр. Каменистий - це локалітети зареєстровані в попередні роки. Локалітети закартовані та взяті під охорону (рис. 1).

Leucocortinarius bulbiger - вид з диз'юнктивним ареалом. Росте в хвойних, мішаних та листяних лісах. Плодоносить з вересня до кінця жовтня. Трапляється в Західному, Правобережному та Лівобережному Лісостепу, Гірському Криму [7].

На території НПП «Гуцульщина» в попередні роки зафіксовано один локаліт Leucocortinarius bulbiger на території Шешорського ПНДВ [6]. Вид трапляється дуже рідко. В 2020 р. виявлено ще два нових локалітети: 29.07. в Шешорському ПНДВ, (кв. 22, вид. 2), 
буковому лісі з домішкою смереки, та 27.10. в Косівському ПНДВ, постійній пробній площі (ППП) № 9, ялицево-буковому лісі. Локалітети закартовані та взяті під охорону (рис. 1).

Mutinus caninus - вид 3 диз'юнктивним ареалом. Росте в хвойних, листяних та змішаних лісах. Плодоносить з липня до кінця жовтня. В Україні поширений майже в усіх областях [7]. В Українських Карпатах вид трапляється в КБЗ, НПП «Синевир», Ужанському НПП [2].

На території НПП «Гуцульщина» Mutinus caninus зареєстровано в усіх трьох ПНДВ та Яблунівському лісництві (ДП «Кутське лісове господарство») [6]. Вид трапляється рідко. В 2020 році виявлено ще чотири нових місця зростання: 28.07. в Старокутському ПНДВ (кв. 24, вид. 9), смереково-буковому лісі, 29.07. - Шешорському ПНДВ (кв. 17, вид.17), ялицевобуковому лісі, 05.07. - Кутському лісництві (ДП «Кутське лісове господарство»), (кв. 11, вид. 12; кв. 25, вид. 21), буковому лісі, 30.07. - Кобаківському лісництві РП «Райагроліс», (кв. 18), буковому лісі. Також бачили M. caninus у локалітетах виявлених в попередні роки: 26.06., 9.07., 10.08., 22.10. - Старокутському ПНДВ, хр. Голиця, смереково-буковому лісі; 7.07., 11.08. в Косівському ПНДВ, ур. Каменистий, ялицево-буковому лісі. Слід відмітити, що в НПП «Гуцульщина» M. caninus трапляється в мішаних лісах 3 Fagus sylvatica L. Локалітети закартовані та взяті під охорону (рис. 1).

Phylloporus pelletieri - вид 3 диз'юнктивним ареалом. Росте в листяних, мішаних, та соснових лісах. Плодоносить 3 серпня до кінця вересня. В Україні вид поширений лише в Закарпатській обл. [7]. В Українських Карпатах вид виявлений в КБ3, Карпатському НПП, Ужанському НПП [2].

На території НПП «Гуцульщина» Phylloporus pelletieri зафіксований в Шешорському ПНДВ та Кутському лісництві (ДП «Кутське лісове господарство») [6]. Вид трапляється на території парку дуже рідко. В 2020 р. зафіксовано ще один новий локалітет 10.08. в Старокутському ПНДВ, хр. Голиця, сосново-буковий ліс. Локалітет закартовано та взято під охорону (рис. 1).

Polyporus umbellatus - вид з диз'юнктивним ареалом. Росте в листяних та мішаних лісах. Плодоносить з червня до жовтня. В Україні поширений в Передкарпатті, Сумській, Львівській, Тернопільській, Черкаській, Херсонській та Харківській областях. [7]. В Українських Карпатах вид зареєстрований в КБЗ, Карпатському НПП, НПП «Синевир», Ужанському НПП [2].

На території НПП «Гуцульщина» Polyporus umbellatus трапляється в Косівському та Старокутському ПНДВ, Косівському лісництві (ДП «Кутське лісове господарство»), Кобацькому лісництві (РП «Райагроліс») [6]. В 2020 р. виявлено нові місцезростання в Старокутському ПНДВ, ур. Хоминський (кв. 5, вид. 33), буковому лісі, та 14.07. в Косівському ПНДВ, ППП №9, ялицево-буковому лісі. Крім того реєстрували плодові тіла P. umbellatus в червні - липні на вже відомих раніше місцях: в Косівському лісництві (ДП «Кутське лісове господарство», околиці сс. Хімчин, Вербовець), дубовому лісі; 11.08. в Косівському ПНДВ, ур. Каменистий, смереково-ялицево-буковому лісі. Локалітети закартовані та взяті під охорону (рис. 1). Вид підтримується в колекції чистих культур НПП «Гуцульщина», виконується програма «Відтворення рідкісних макроміцетів».

Strobilomyces strobilaceus - неморальний вид 3 диз'юнктивним ареалом. Росте в листяних, хвойних лісах. Плодоносить з липня до вересня. В Україні поширений на Передкарпатті, Західноукраїнських лісах та Розточчі [7]. В Українських Карпатах вид зареєстрований в КБЗ, НПП «Синевир», НПП «Сколівські Бескиди», Ужанському НПП [2].

В НПП «Гуцульщина» Strobilomyces strobilaceus поширений на всій території [6]. Вид трапляється поодиноко, щорічно. В 2020 р. новий локалітет відмічено 09.07. в Старокутському ПНДВ, хр. Голиця (кв. 3, вид. 2), смереково-буковому лісі. Також плодові тіла бачили на вже 
відомих локалітетах: 27.07. в Шешорському ПНДВ, Мертве озеро, буковому лісі; 13.08. на хр. Сокільський (ДП «Кутське лісове господарство»), буковому лісі та 24.09. в Косівському ПНДВ, ур. Каменистий, ялицево-буковому лісі. Локалітети закартовані та взяті під охорону (рис. 1).

Tricholoma focale - бореальний вид 3 диз'юнктивним ареалом. Росте в соснових лісах. Плодоносить 3 серпня до кінця жовтня. В Україні вид поширений в Полтавській, Дніпропетровській, Луганській та Херсонській областях [7].

На території НПП «Гуцульщина Tricholoma focale вперше виявлена в 2005 році під час мікологічних експедицій к. с-г. н. І.В. Базюк (Національний лісотехнічний університет України) [1]. Проте в наступні роки вид не фіксували. Вид дуже рідкісний в парку.

20.10 .2020 р. знайдено 2 плодові тіла в Старокутському ПНДВ, хр. Голиця, сосновий ліс це новий локалітет цього виду в НПП «Гуцульщина» та на сьогодні єдине відоме місцезротання в Українських Карпатах. Локалітет закартовано та взято під охорону (рис. 1).

Крім рідкісних видів ЧКУ мікобіота НПП «Гуцульщина» включає гриби, що включені до списків МСОП. В 2020 р. фіксували плодові тіла Cortinarius caperatus (IUCN) 3 критерієм загроженості LC (стабільний). Вид включений до МСОП 26 лютого 2018 р. Жодні заходи щодо збереження цього виду не потрібні, оскільки він дуже поширений і для нього немає серйозних загроз. Немає свідчень про будь-яке зниження чисельності [5].

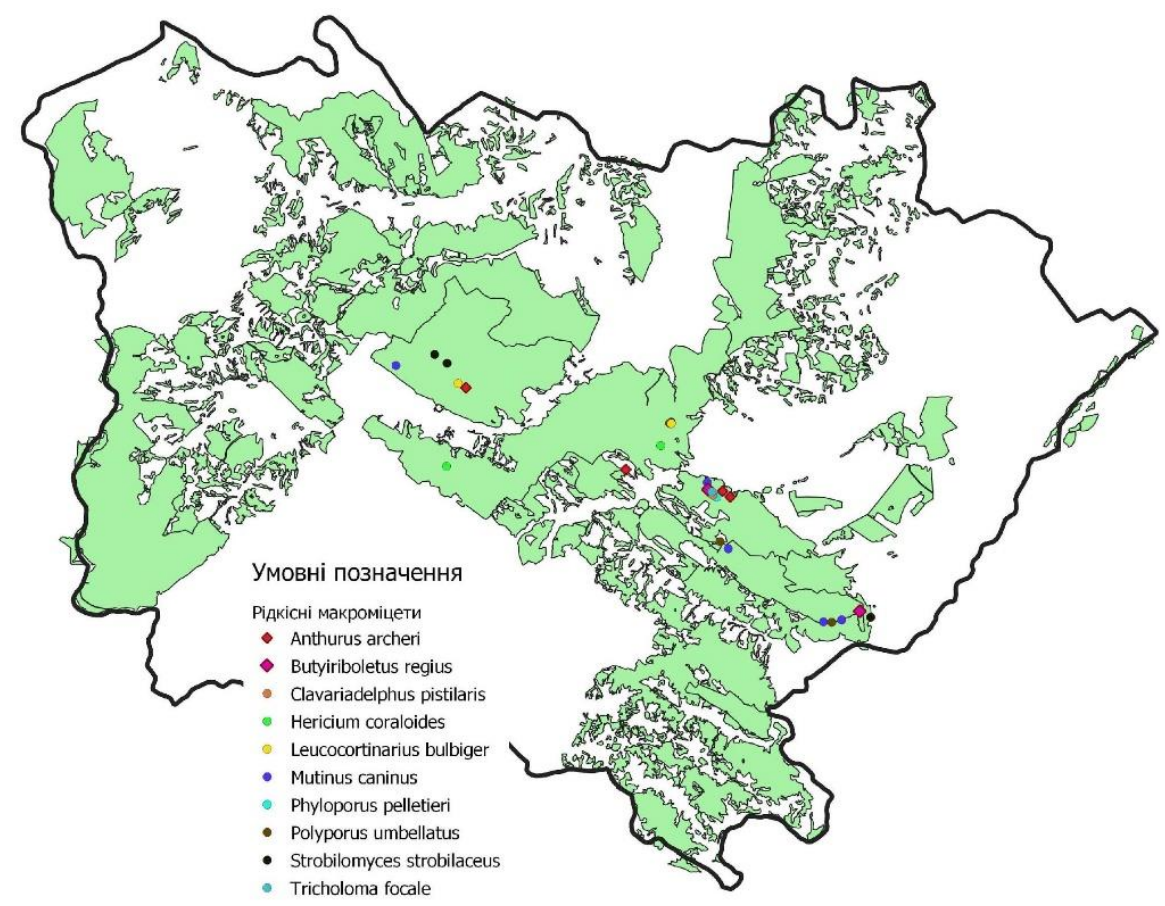

Рисунок. Локалітети рідкісних видів макроміцетів НПП «Гуцульщина», виявлених в 2020 p.

Cortinarius caperatus - бореальний вид. Росте в хвойних та листяних лісах. Утворює мікоризу з соснами, ялинами, дубами, буками, березами. Плодоносить з серпня до кінця вересня. В Україні трапляється на Правобережному Поліссі, в Лівобережному Злаковому Степу [3]. В Українських Карпатах вид виявлений в КБЗ, Природному заповіднику «Горгани», НПП «Верховинський», Карпатському НПП [2]. 
На території НПП «Гуцульщина» це звичайний вид, плодоносить щорічно, в деякі роки $(2015,2018,2020)$ масово.

За результатами мікологічних досліджень на території Національного природного парку «Гуцульщина» впродовж 2020 р. було зареєстровано та закартовано 11 видів рідкісних видів макроміцетів, що включені до списків ЧКУ та МСОП. Серед них 4 види: Leucocortinarius bulbiger, Phylloporus pelletieri, Clavariadelphus pistillaris, Tricholoma focale трапляються в НПП «Гуцульщина» дуже рідко та поодиноко, 4 види: Mutinus caninus, Strobilomyces strobilaceus, Butyriboletus regius, Hericium coralloides плодоносять майже щорічно, але є рідкісними. Polyporus umbellatus плодові тіла утворює щорічно, в деякі роки плодоносить масово і $€$ чимало локалітетів цього виду. Такі види, як Anthurus archeri та Cortinarius caperatus $€$ звичайними для НПП «Гуцульщина» і не потребують охорони.

\section{Література:}

1. Базюк І.В. Мікофлора Національного природного парку «Гуцульщина» // Літопис природи Т. ІІІ, 2006. - С. 188-198.

2. Дудка І.О., Гелюта В.П., Придюк М.П. та ін. Гриби заповідників і національних природних парків Українських Карпат / за ред. В.П. Гелюти. - НВП «Видавництво «Наукова думка» НАН України», 2019. - 214 с.

3. Зерова М.Я., Сосін П.Є, Роженко Г.Л. 1979. Визначник грибів України в 5-ти томах, Т. 5, книга 2. / Відп. ред. Д.К. Зеров, В.Ф. Пересипкін. Київ: Наукова думка, 1979. - 564 с.

4. Кибби Дж. 2009. Атлас грибов: Определитель видов. СПб.: Амфора, 269 с

5. МСОП. 2017. Категорії та критерії червоного списку МСОП: Версія 3.1. 2-ге вид. Київ, $36 \mathrm{c}$.

6. Фокшей C.I. Знахідки макроміцетів, занесених до Червоної книги України в НПП «Гуцульщина» // Знахідки рослин і грибів Червоної книги та Бернської конвенції (Резолюція 6). - Т. 1 / наук. ред. А. А. Куземко. - Київ - Чернівці : Друк Арт, 2019. - С. 426-430. - (Серія: «Conservation Biology in Ukraine»; вип. 11).

7. Червона книга України. Рослинний світ. 2009. / за ред. Я.П. Дідух. Київ: Глобалконсалтинг, с. 780-836.

8. Garnweidner E. 1994. Mushrooms and Toadstools of Britain and Europe. London: Harper Collins Publishers, 255 pp.

9. Index fungorum. http //www.indexfungorum.org/names.asp. 